\section{Cytokinin and Light Intensity Regulate Flowering of Easter Lily}

\author{
Yin-Tung Wang \\ Department of Horticultural Sciences, Texas A\&M University System \\ Agricultural Research and Extension Center, 2415 East Highway 83, Weslaco, \\ TX 78596
}

\section{Additional index words. Lilium longiflorum, plant growth regulator}

\begin{abstract}
Lilium longiflorum Thunb. 'Nellie White' plants were selected when their first flower buds reached 2 or $5 \mathrm{~cm}$ in length, sprayed with $2 \mathrm{~mL}$ of PBA at 0 or $500 \mathrm{mg} \cdot \mathrm{L}^{-1}$, and then placed under 1440 or $60 \mu \mathrm{mol} \cdot \mathrm{m}^{-2} \cdot \mathrm{s}^{-1}$ photosynthetic photon flux (PPF) during flowering. PBA resulted in delayed anthesis and increased dry matter accumulation in flowers under the high PPF but had no effect under the low PPF. PBA did not decrease the severity of flower bud abortion under the low PPF. Application of PBA induced the formation of numerous bulbils in the leaf axils. Regardless of PPF, PBA-treated plants had less dry weight in the main bulbs than the control plants. Chemical name used: $\mathrm{N}$ (phenylmethyl)-9-(tetra-hydro-2H-pyran-2-yl)-9H-purin-6-amine (PBA).
\end{abstract}

Heins et al. (1982) determined that shortterm complete darkness at early stages of development had no effect on Easter lily (Lilium longiflorum Thunb.) flower count. Miller and Langhans (1989) found that an $85 \%$ light exclusion $\left(\approx 1.4 \mathrm{~mol} \cdot \mathrm{m}^{-2} \cdot \mathrm{d}^{-1}\right.$ photons $)$ from bud initiation promoted Easter lily flower bud abortion. Wang and Gregg (1992) reported that all flower buds aborted as a result of prolonged exposure to complete darkness when the largest buds on plants were $\approx 7 \mathrm{~cm}$ long. However, none examined a possible solution to reduce bud abortion under unfavorable light conditions.

Foliar application of ${ }^{6} \mathrm{~N}$-benzylaminopurine at $500 \mathrm{mg} \cdot \mathrm{L}^{-1}$ immediately before simulated shipping drastically decreased the degree of Easter lily leaf yellowing after 4 weeks in darkness (Han, 1995). Because overcast skies can result in flower bud abortion (Miller and Langhans, 1989), the application of cytokinin to Easter lily plants while flower buds are small might assist in their development under low light conditions.

\section{Materials and Methods}

'Nellie White' bulbs (20 to $23 \mathrm{~cm}$ in circumference) were vernalized and planted one per 2.6-L pot on 28 Nov. 1990 using Sunshine Mix No. 1 (Fisons Horticultural Products, Vancouver, B.C.). Pots were placed on a greenhouse bench with $1300 \mu \mathrm{mol} \cdot \mathrm{m}^{-2} \cdot \mathrm{s}^{-1}$ maximum photosynthetic photon flux (PPF) measured at solar noon. Plants were fertigated with water containing $20 \mathrm{~N}-8.7 \mathrm{P}-16.6 \mathrm{~K}$ soluble fertilizer with trace elements (Grace-Sierra, Fogelsville, Pa.) at $1.5 \mathrm{~g} \cdot \mathrm{L}^{-1}$ and they occasionally were flushed with water. Shoots started to emerge in late December. The air in the

Received for publication 8 Sept. 1995. Accepted for publication 7 May 1996. The cost of publishing this paper was defrayed in part by the payment of page charges. Under postal regulations, this paper therefore must be hereby marked advertisement solely to indicate this fact. greenhouse was maintained between $28{ }^{\circ} \mathrm{C}$ (day maximum) and $12{ }^{\circ} \mathrm{C}$ (night minimum) until 15 Mar. 1991, after which it ranged between 35 and $20^{\circ} \mathrm{C}$.

Twenty-four uniform plants were selected on 27 Feb. 1991 and again on 6 Mar. when their largest flower buds were 2 and $5 \mathrm{~cm}$ long, respectively. On each date, flower buds on half of these plants were sprayed with $2 \mathrm{~mL}$ of water containing PBA at $500 \mathrm{mg} \cdot \mathrm{L}^{-1}$ (Abbott Laboratories, North Chicago, Ill.) and $0.05 \%$ Tween 20 (Fisher Scientific, Fair Lawn, N.J.). I did not attempt to prevent PBA solution from running down the plant and wetting the bases of leaves because it is difficult to do so in a commercial operation. Control plants were sprayed with $2 \mathrm{~mL}$ of water containing $0.05 \%$ Tween 20. The Weslaco, Texas, area received $611 \mathrm{~mol} \cdot \mathrm{m}^{-2}$ of photons between $27 \mathrm{Feb}$. and 5 Mar. and $2430 \mathrm{~mol} \cdot \mathrm{m}^{-2}$ between 6 Mar. and 7 Apr. Half of the plants treated on each date

Table 1. Effect of developmental stage and PBA on Easter lily flowering under two light levels.

\begin{tabular}{|c|c|c|c|c|c|c|c|c|}
\hline \multirow{3}{*}{$\begin{array}{l}\text { Flower } \\
\text { bud } \\
\text { length } \\
(\mathrm{cm})^{\mathrm{z}} \\
\end{array}$} & \multirow{3}{*}{$\begin{array}{c}\text { PBA concn } \\
\left(\mathrm{mg} \cdot \mathrm{L}^{-1}\right)\end{array}$} & \multirow{3}{*}{$\begin{array}{c}\text { Flower } \\
\text { bud } \\
\text { abortion } \\
(\%)\end{array}$} & \multicolumn{4}{|c|}{ Flower dry mass (g) } & \multirow{3}{*}{$\begin{array}{l}\text { Mean } \\
\text { flower } \\
\text { length } \\
(\mathrm{cm})\end{array}$} & \multirow{3}{*}{$\begin{array}{l}\text { Days to } \\
\text { anthesis }\end{array}$} \\
\hline & & & \multicolumn{3}{|c|}{ Flower no. } & \multirow[b]{2}{*}{ Total } & & \\
\hline & & & 1 & 2 & 3 & & & \\
\hline \multicolumn{9}{|c|}{ Low light } \\
\hline \multirow[t]{2}{*}{2} & 0 & $100 \mathrm{a}$ & $0.08 \mathrm{~b}$ & $0.07 \mathrm{~b}$ & $0.05 \mathrm{~b}$ & $0.21 \mathrm{~b}$ & --- & --- \\
\hline & 500 & $100 \mathrm{a}$ & $0.09 \mathrm{~b}$ & $0.07 \mathrm{~b}$ & $0.06 \mathrm{~b}$ & $0.22 \mathrm{~b}$ & -- & --- \\
\hline \multirow[t]{2}{*}{5} & 0 & $76 \mathrm{a}$ & $0.77 \mathrm{a}$ & $0.72 \mathrm{a}$ & $0.49 \mathrm{~b}$ & $1.98 \mathrm{a}$ & --- & --- \\
\hline & 500 & $67 \mathrm{a}$ & $1.00 \mathrm{a}$ & $0.94 \mathrm{a}$ & $0.97 \mathrm{a}$ & $2.92 \mathrm{a}$ & --- & --- \\
\hline \multicolumn{9}{|c|}{ High light } \\
\hline \multirow[t]{2}{*}{2} & 0 & $0 \mathrm{a}$ & $1.54 \mathrm{c}^{\mathrm{y}}$ & $1.63 \mathrm{c}$ & $1.61 \mathrm{c}$ & $4.78 \mathrm{c}$ & $18.2 \mathrm{~b}$ & $119 \mathrm{~b}$ \\
\hline & 500 & $2 \mathrm{a}$ & $1.99 \mathrm{~b}$ & $2.01 \mathrm{ab}$ & $2.08 \mathrm{ab}$ & $6.05 \mathrm{ab}$ & $19.1 \mathrm{a}$ & $124 \mathrm{a}$ \\
\hline \multirow[t]{2}{*}{5} & 0 & $0 \mathrm{a}$ & $1.77 \mathrm{~b}$ & $1.77 \mathrm{bc}$ & $1.80 \mathrm{bc}$ & $5.31 \mathrm{bc}$ & $18.7 \mathrm{ab}$ & $115 \mathrm{c}$ \\
\hline & 500 & $0 \mathrm{a}$ & $2.21 \mathrm{a}$ & $2.22 \mathrm{a}$ & $2.25 \mathrm{a}$ & $6.67 \mathrm{a}$ & $19.2 \mathrm{a}$ & $123 \mathrm{a}$ \\
\hline \multicolumn{9}{|c|}{ F significance } \\
\hline Light (L) & & $* * *$ & $* * *$ & $* * *$ & $* * *$ & $* * *$ & & \\
\hline Size (S) & & NS & $* * *$ & $* * *$ & $* * *$ & $* * *$ & NS & $* * *$ \\
\hline PBA (P) & & NS & $*$ & $*$ & $* *$ & $* *$ & $*$ & $* * *$ \\
\hline $\mathrm{L} \times \mathrm{S}$ & & NS & $*$ & $* *$ & $*$ & $*$ & & \\
\hline $\mathrm{L} \times \mathrm{P}$ & & NS & $*$ & NS & NS & NS & & \\
\hline $\mathrm{S} \times \mathrm{P}$ & & NS & NS & NS & NS & NS & $*$ & * \\
\hline $\mathrm{L} \times \mathrm{S} \times \mathrm{P}$ & & NS & NS & NS & NS & NS & & \\
\hline
\end{tabular}

${ }^{2}$ When treatments were initiated.

'Mean separation in each column and within each light level by Duncan's multiple range test when $P \leq 0.05$. ss, $, * * *, * * *$ Nonsignificant or significant at $P \leq 0.05,0.01$, or 0.001 , respectively. 
increased flower weight was due to longer developmental time or the accumulation of nonstructural carbohydrates. Nightingale (1979) reported that date of flowering was not affected by foliar applications of PBA at 500 $\mathrm{mg} \cdot \mathrm{L}^{-1}$ when plants were 5 or $15 \mathrm{~cm}$ tall. In my test, PBA also caused a few deformed flowers that split as they developed.

The results of this experiment suggest that the application of PBA at $500 \mathrm{mg} \cdot \mathrm{L}^{-1}$ to developing Easter lily flower buds does not prevent flower bud abortion under stress induced by low light.

\section{Literature Cited}

Han, S.S. 1995. Growth regulators delay foliar chlorosis of Easter lily leaves. J. Amer. Soc. Hort. Sci. 120:254-258.

Heins, R.D., H.F. Wilkins, and W.E. Healy. 1982. The influence of light on lily (Lilium longiflorum Thunb.) II. Influence of photoperiod and light stress on flower number, height, and growth rate. J. Amer. Soc. Hort. Sci. 107:335-338.

Miller, W.B. and R.W. Langhans. 1989. Reduced irradiance affected by dry weight partitioning in Easter lily. J. Amer. Soc. Hort. Sci. 114:306-309. Nightingale, A.E. 1979. Bulb formation on Lilium longiflorum Thunb. cv. Nellie White by foliar application of PBA. HortScience 14:67-68.

Wang, Y.T. and P.J. Breen. 1984. Respiration and weight changes of Easter lily flowers during development. HortScience 19:702-703.

Wang, Y.T. and L.L. Gregg. 1992. Developmental stage, light, and foliage removal affect flowering and bulb weight of Easter lily. HortScience $27: 824-826$.

Wilkins, H.F., K. Grueber, W.E. Healy, and H.B. Pemberton. 1986. Minimum fluorescent light requirements and ancymidol interactions on the growth of Easter lily. J. Amer. Soc. Hort. Sci. 111:384-387. 